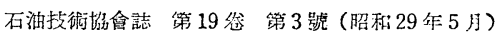

JOURNAL OF THE JAPANESE ASSOCIATION OF PETRPLEUM TECHNOLOGISTS

VOL. 19, NO. 3 (May, 1954)

\author{
圧入ガスチャンネリングとガス比重お \\ よび產出ガス油比の実驗的關係*
}

眞 貝 耀 - ${ }^{* *}$

(昭和 29 年 6 月 1 日受理)

\title{
Relationship between Specific Gravity of Gas and Gas Oil Ratio
}

By

\section{Yōichi ShIngaI}

\begin{abstract}
Measurement of specific gravity of gas of a well which is producing under high gas oil ratio is used for assuming the amount of channelled gas in gas injection method.
\end{abstract}

\section{緒 言}

八橋油田第 VIII 層, 第 IX 層では, 圧力維持の立場か ら，構造上頂部の高野 R. 61 㧊よび外旭川 R. 43 の両 井を圧入井とし，ガス圧入を実施している。しか子近時 油層状況は逐次変化して，压入ガスがチャンネリングし ていることが明白になつた。従つてプールの産出がス油 比にチャンネリングせるガスを加えて評価する㲘念があ る。しからば, チャンネリングガス量がぞの位存在する かといらことは, マテリアリアルバランスの計算過程を 回收量と油層圧力とからた兄ずチェックして，油層状況 が今いかなるステージにあるのかを克明に精度よく研究 してゆくことから，およその判定はつくけれども，量的な チャンネリングガス量を決定する確定的な手段にはなら ない。そこで戍入せるドライガスが，ある特定の層に， シャープなチャンネリングを生じているという前提にも とづいて1), 油層そのもののーービーなガスの比重と,ド ライガスの比重，これ等の 2 者がある割合で混合した場 合の産出ガスの比重から，チャジネリングガス量を推定 計算したところ，量的に把握できると思われるに至つた ので，その実測の過程を報告して諸賢の批判を得たい。

\section{計算の根拠}

今簡単に圧入ガスが地下でチャンネリングを生じて,

$*$ 昭和 29 年 5 月 6 日第 19 回石油技攸協會總會個人講演

** 需石本社生產部

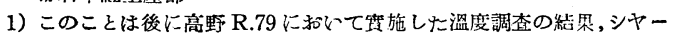
ブなチヤンネリングジーンが利明した。 このゾーンをスクイーズせるところガス淮此は低下した。
油層中の溶解ガスと混合した場合に, 産出したガスの比 重は溶解ガスそのもの比重より軽くなるはずである。従 つて次の関係が生ずるであろらと考えられる。

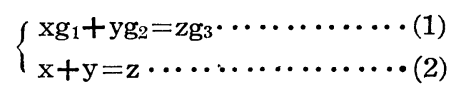

ここで $\mathrm{x}$ ：全産出ガス中の溶解ガスの量。

$\mathrm{y}$ ： 全産出ガス中のチャンネリングせるガス の量。

$z$ ：全産出ガス量。

$\mathrm{g}_{1}$ ：溶解ガスの比重。

$\mathrm{g}_{2}$ : 圧大ガスの比重。

$\mathrm{g}_{3}$ : 産出ガスの比重。

これは次の如く表わし得る。すなわち

$$
\frac{\mathrm{y}}{\mathrm{z}}\left(\mathrm{g}_{2}-\mathrm{g}_{1}\right)+\mathrm{g}_{1}-\mathrm{g}_{3}=0 \ldots \ldots \ldots \ldots(3)
$$

今 $\frac{\mathrm{y}}{\mathrm{z}}=\mathrm{X}, \mathrm{g}_{2}-\mathrm{g}_{1}=\mathrm{A},-\mathrm{g}_{3}=\mathrm{Y}, \mathrm{g}_{1}=\mathrm{C}$ とおけば(3) 式は $\mathrm{AX}+\mathrm{Y}+\mathrm{C}=0$

となり X, Y について直線の方程式を示す。しかして 王入ガスの比重の平均值は 0.632), 溶解ガスの比重はほ とんど13)であるから，そのグラフは第1図の如き簡単 な形で表わし得る。從つて各坑井の油層状態を表わすガ スサンプルについて，それぞれの比重測定を実施し，第 1 図からチャンネリングガスの 全産出ガス量に対する 100 分率を読みとれば，坑井個々にチャンネリングガス

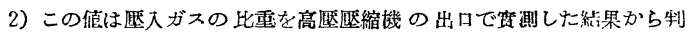
明した。

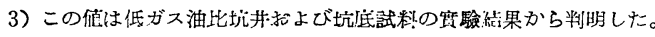


量が計算できることになる。かつ匨入ガスのチャンネリ ング現象が進行すれば，亲すなすが油比が高くなるこ とが考觉られるので，このことは採取方法打よびチャン ネリングの断定についての根本的な現象であるはずであ るから，このことについての観測も 併せて実施した結 果, ガス比重との相関的関倸があることが見出された。 もちろ几坑升を個々にパーフォーマンスカーブから検討 し, 坑井の成功当初から油層状況の暴常な子の等も考察 の基礎として，試料採取および判定に資した。

\section{ガス試料探取および試験方法}

ガス試料の採取方法を第 2 図に示す。セパレーターA からガスフローラィンを通つたガスはオリフィスメータ 一Cで諻されて，プラントに入る。そこでフローラィ ンを図示の如く別口にひいて，その先端にオリフィスを 附す。オリフィスの直前から一方はUゲーヂ, 他方はサ ンプル捕收瓶に通ずるゴムホースがある。従つて産出ガ スはオリフィスによつて制限されたセパレーターE力で 捕收される。今回の採取に際してはUゲーヂの水銀杜が 1 时になるようにして採取した。採取瓶は 5 リットルで ある。採取する前汇約 10 分間ガスを放散し，坑非の ガスの流動を正常にし，またパイプラィン中の重質分そ の他を排出して後, 水銀杜 1 时をたえず 保ちつ〉採取した。採取には約 5 分を要 した。この試料はシーリングボトルら゙に よつて得た結果で計算した。ストップウ ォッチによる時間の読みは, 3 回測定の 算術平均值をとつた。特に多数坑井の実 験であるために，採取状況・測定方法に は可能な限り状況を同一ならしむる如く 努めた。

\section{観 察結果}

高ガス油比で密閉中の坑井についての ガス比重 外旭川 R. 18 井(第VIII 層) は高ガス油比のために密閉中の坑井であ る。密閉当時ガス油比は 1,000 以上であ つた（溶解ガス油比は約 100 前後であ る)。

従つて採油を開始した場合のガス試料 を採取すれば, 当然ガス油比がドライガ スの比重に接近するであろらという想定 にもとづいて，採取にあつた。

第 3 図に開放後の時間と, その時のガ

4）ガス試粈探取方法々はよだ研究の余地が老分あり，今後成るべく人手

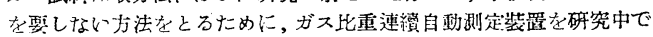
ある。
第 1 図 Amount of Channelling Gas vs Sp. Gr. of Produced Gas

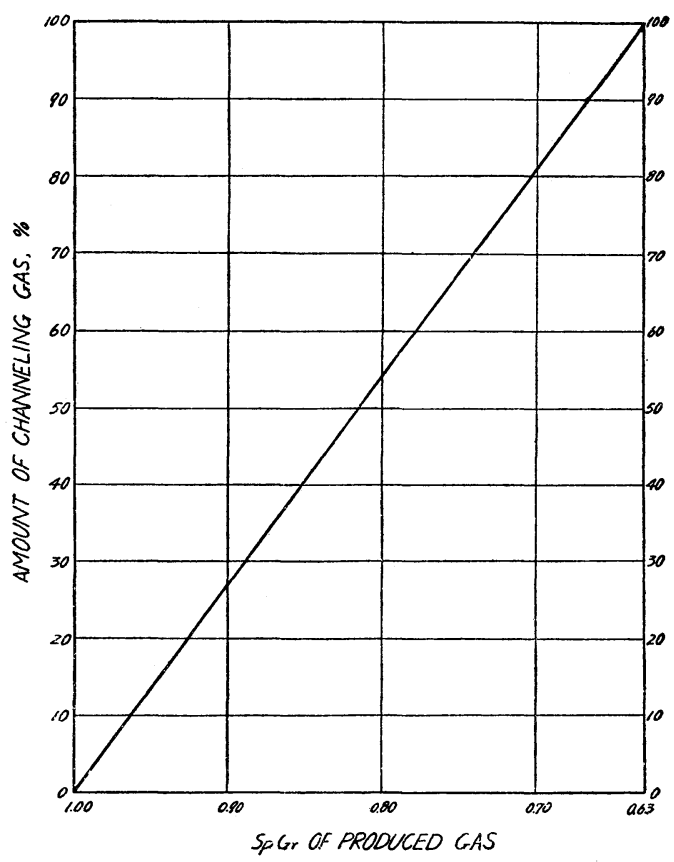

第 2 図

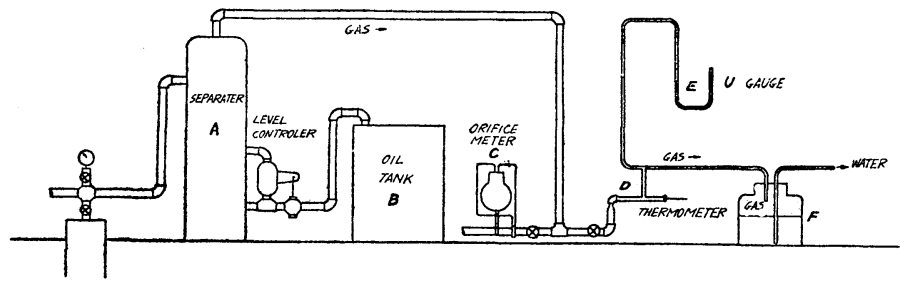

第 3 図 Sp. Gr. of Produced Gas vs Time (S.R 18-VIII, Bean 5)

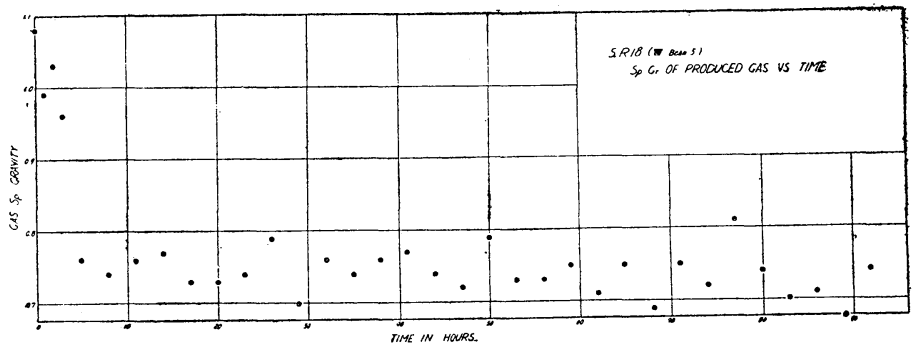

5）シーリングボツトルによる梁测值は米國から輸入したエドワードガ ス比重計とほとんど差買はない。兩者とも上0.1\%位の詇差籍囲に ある。 
ス比重の関係を示す。開放後の時間とガス比重の一覧表 は第 1 表の如くである。

第 4 図 Sp. Gr. of Produced Gas vs Time (K.R 67-VIII, Bean 6)

第 1 表

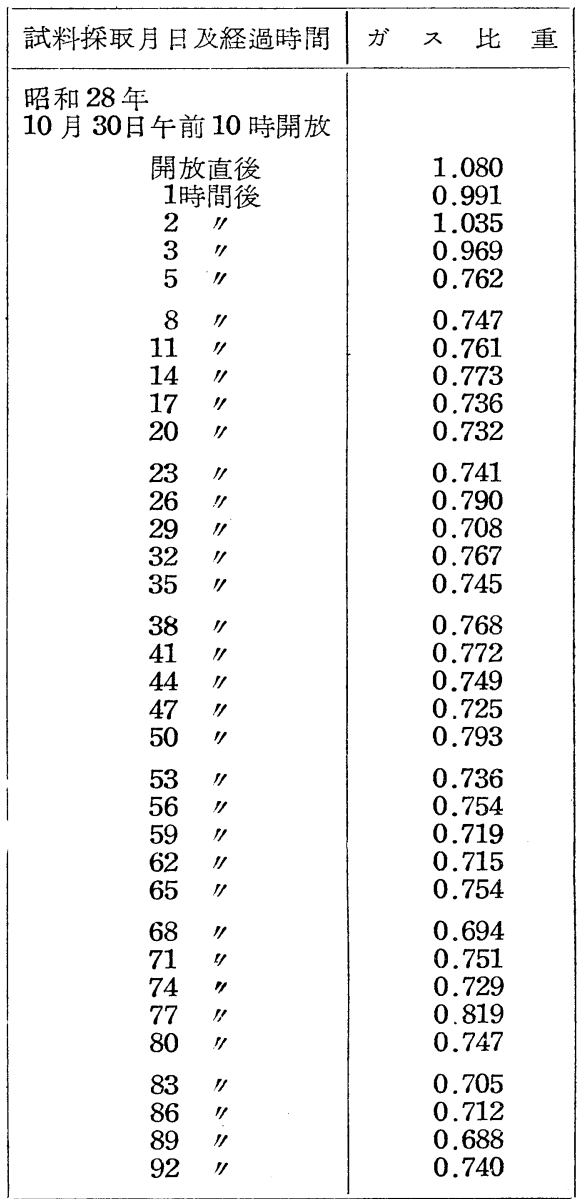

第 3 図和よび表 1 の如くマンスリーテスト井は開放当 初はパイプラフィン・セパレーター等の残留分のため か，ガス比重は大となり，4〜5時間後におよそコンスタ ントの值を示し, 0.7 0.8の間で波型を示しているよう に見受けられる。この時のガス油比は平均 1,200であつ た。このテストで明暸であるように，か〉る坑井のガス が実際の油層状況を評価するに足る值を現出するに至る には，開放後数時間を要することが明瞭である。從つて 8 月実測した值が 0.966〜1.063 であつた 原因は，開放 直後の採取の結果であつたことが判然とした。従つてガ ス比重を測定する際には，特にマンスリーテスト井等の 密閉井では余程の慎重を要する。

正常な採油を続けている坑井についてのガス比重 高 野 R. 67 井（VIII 層）はビーン 6/64, "' 高野 R. 75 井 (VIII 層) はビーン $4 / 64$ "にて 1 日連続採油を行つてい る。ガス油比はそれぞれ平均 440,230 である。これ等

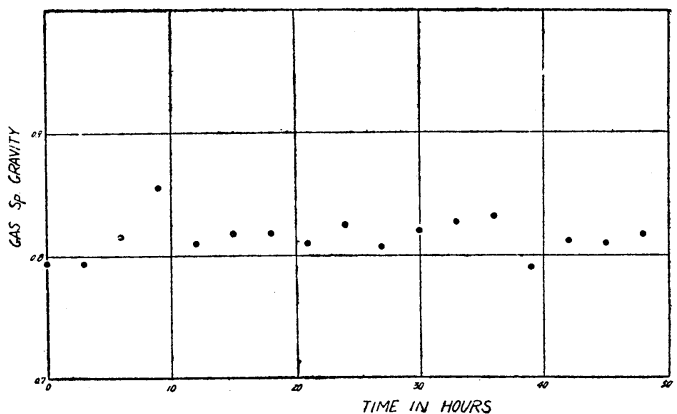

第 5 図 Sp. Gr. of Produced Gas vs Time (K.R. 75--VIII, Bean 4)

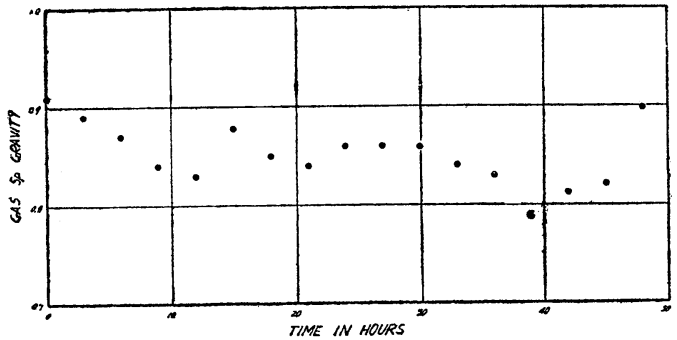

第 2 表

\begin{tabular}{|c|c|c|c|}
\hline \multicolumn{2}{|c|}{ 経過時間 } & $\begin{array}{l}\text { KR } 67 \text { (28-11-2, } \\
10 \text { 時 } 50 \text { 分 a.m. } \\
\text { 探集開始) } \\
\text { ガス比重 }\end{array}$ & $\begin{array}{l}\text { KR 75(28-10-31, } \\
9 \text { 時 30 分 a.m. 探 } \\
\text { 取開始) } \\
\text { ガス比重 }\end{array}$ \\
\hline \multirow{2}{*}{\multicolumn{2}{|c|}{$\begin{array}{r}\text { 探取開始時 } \\
3 \text { 時間後 }\end{array}$}} & 0.795 & 0.916 \\
\hline & & 0.795 & 0.892 \\
\hline 6 & "I & 0.818 & 0.876 \\
\hline 9 & "I & 0.856 & 0.844 \\
\hline 12 & "I & 0.810 & 0.832 \\
\hline 15 & "I & 0.818 & 0.884 \\
\hline 18 & " & 0.818 & 0.856 \\
\hline 21 & " & 0.810 & 0.844 \\
\hline 24 & " & 0.825 & 0.859 \\
\hline 27 & "I & 0.807 & 0.869 \\
\hline 30 & $1 "$ & 0.820 & 0.867 \\
\hline 33 & "I & 0.827 & 0.840 \\
\hline 36 & $" 1$ & 0.831 & 0.832 \\
\hline 39 & "I & 0.790 & 0.795 \\
\hline 42 & "I & 0.812 & 0.810 \\
\hline 45 & $"$ & 0.809 & 0.821 \\
\hline 48 & $" 1$ & 0.816 & 0.897 \\
\hline
\end{tabular}

の坑井の時間とガス比重の関係は第 4 図・第 5 図の如く であり，前記外旭川 R. 18 北と同様のイレギュラリテ イーを示しているが， 67 井においては 0.8 近边， 75 米 
第 6 図 Gas Sp. Gr. vs Gas-Oil Ratio, VIII Zone

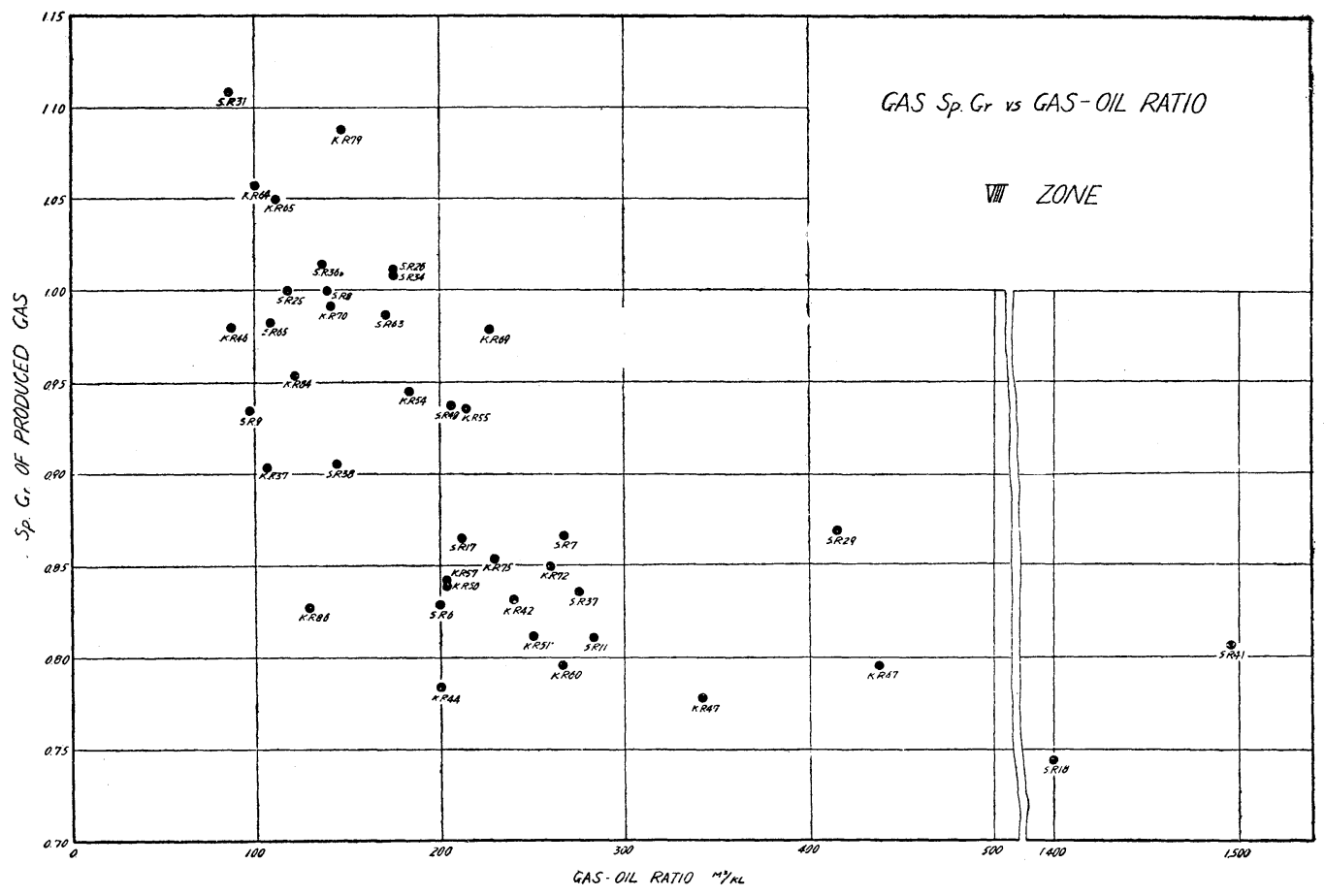

第 7 図 Gas Sp. Gr. vs Gas-Oil Ratio, IV Zone

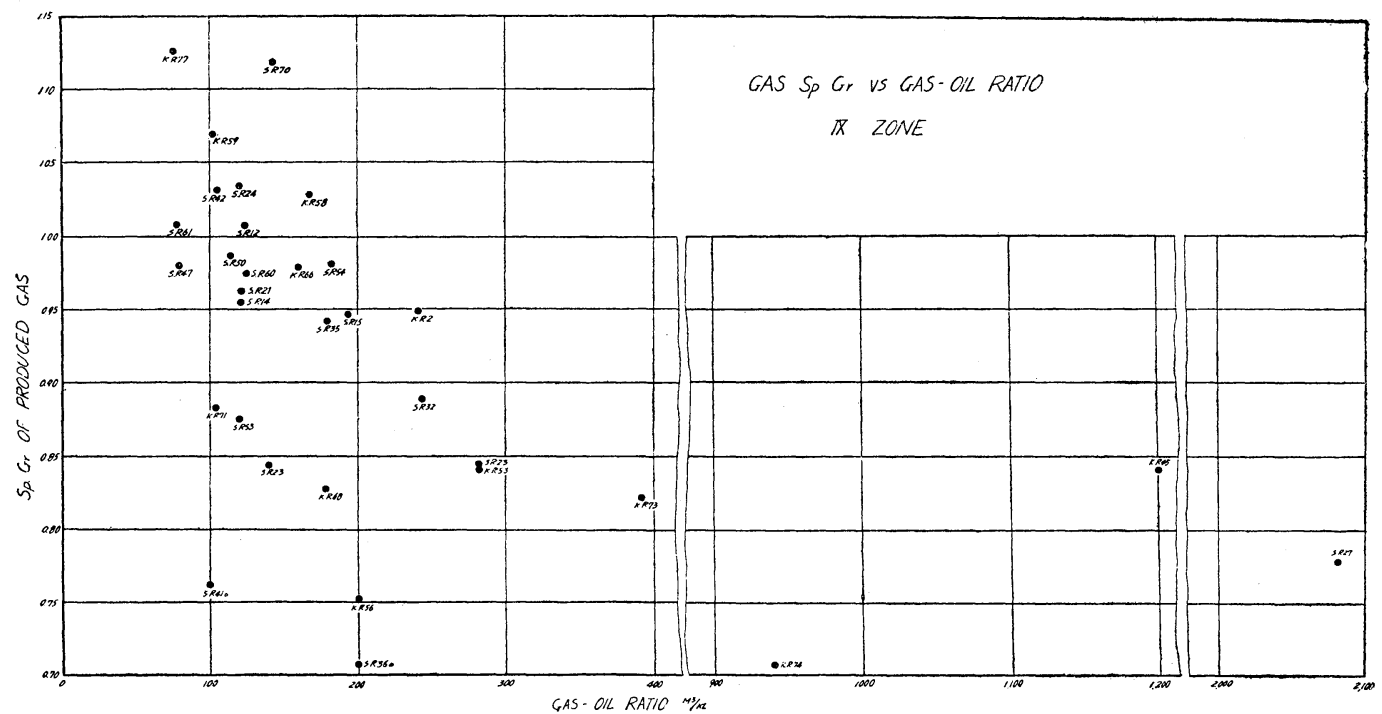

は0.85近辺に集つていることがわかる。これ等の值を 表にすれば第 2 表の如くなる。

以上高ガス油比のため密閉中の坑井と，正常な採油を 続けている坑井とについての比重測定の結果から，ガス 油比とガス比重の間には一定の関係があることがわか
る。今第 VIII 層・第 IX 層の全坑井につき，比重測定を 行つた結果，ガス油比とガス比重の関係をプロットす れば第 6 圀・第7図の如くなる。これ等によつてガス油 比とガス比重の間の関係がおよそ推定できる。すなわち 高ガス油比の坑井は压入ガスの比重 0.63 に近づき，低 
ガス油此の坑扑は溶解ガス比重 1 亿近づくことが判明す る。ただしこれ等の関係は直線的ではなく, VIII 層にお いての高ガス油比坑扭外旭川 R. 41 (ガス油比 1496) は 0.762, 外旭川 R. 18(ガス油比 1400) は 0.744, IX 層 にては高野 R. 74(ガス油此の)は 0.707, 高野 R. 45(ガ 入油比 1200) は 0.837, 外旭川 R. 27(ガス油比 2080) は 0.773 であつて，いずれも 0.7 より大きい。すなわちガ ス油比 400 上上位からは䌷線の倾向がブレークして，ガ ス油比の横軸にほぼ平行な傾向を示している。

\section{チャンネリングガスの計算結果}

以上のデーターから第 VIII 層・第 IX 層の全坑井につ いてガス比重の測定を実施して，チャンネリングガス量 を計算する。今との例として外旭川 R. 6 についての昭 和 28 年 8 月 12 日のデーターは次の如くである。

$\begin{array}{ll}\text { 測定比重 } & 0.829 \\ \text { 産出ガス油比 } & 200 \\ \text { 油 量 } & 0.70 \mathrm{kl} / \mathrm{d} \\ \text { ガス量 } & 142 \mathrm{cu} . \mathrm{m} / \mathrm{d}\end{array}$

この比重测定值 0.829 を第 1 困上で読みとれば, 対応 するチヤンネリングガスの 100 分率は $46 \%$ となる。従 つてチヤンネリングガス量法

$$
142 \times 0.46=65 \text { (cu. m) }
$$

となり，油層からのガス量は

$$
142-65=77
$$

となる。従つて真のガス油比は

$$
77 / 0.70=110
$$

である。

このような考え方を基礎として，备データーを整理す れば次の如きリストが得られる。

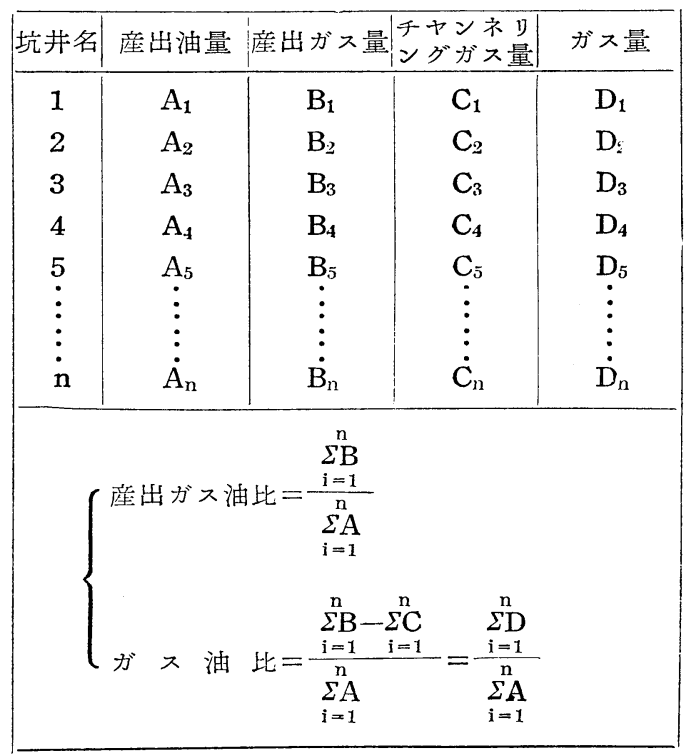

以上の如き簡単な計算を坑井個々について行つた結果 は次の如くである。

\begin{tabular}{|l|c|c}
\hline & 産出ガス油比 & ガ ス 油 比 \\
\hline VIII 層 & 224.4 & 147.1 \\
IX 層 & 200.9 & 147.0 \\
\hline
\end{tabular}

特に各坑井のプロダクションヒストリ一等を詳細に検 討し，開発当初から異常な高がス油比を示す坑并等を除 外して計算すれば次の如くなる。

\begin{tabular}{|c|c|c} 
& $\begin{array}{c}\text { 特殊坑井除外 } \\
\text { 産出ガス油比 }\end{array}$ & $\begin{array}{c}\text { 特殊坑井除外 } \\
\text { ガス油比 }\end{array}$ \\
\hline VIII 層 & 184.4 & 135.7 \\
IX & 166.0 & 130.5 \\
\hline
\end{tabular}

すなわちガス油比の産出ガス油比に対する 100 分率は VIII 層では $74 \% ， I X$ 層では $79 \%$ となる。従つてVIII 層に执いては $26 \%$ ，IX層に㧅いては $21 \%$ \%チャンネ リングせるガス量が，現状として存在するということが 考えられる。

\section{結 論}

これ等の実験結果を綜合してみると、シャープなガス チャンネリング層がある場合，次のことが結論ずけられ る。

（1）ガス油比とガス比重には一定の相関関係が発見さ れた。

（2）ガス比重の測定から，油四のステーヂの早期な場 合に限りチャンネリングガス量を定量できるが，ガス試 料の採取，ガス比重の測定に慎重さを必要とする。

（3）採取および測定方法については，な拈今後の研究 を必要とする。

（4）油層が逐次枯渴して，油層圧力降下のため原油中 から溶解ガスが放出された場合の溶解ガスの比重の変 化，およびドライガスが油層原油中を通過する場合，い かなる割合で溶解ガスと混合するかは，この実測の場合 の考慮にいれていない。従つてこの問題は今後の phase behavior の研究にまつこと大である。

(5) プールガス油比を訐価する場合は，おくまで油層 の連続性が必要であるから，個々の坑井についての各方 面からの油層特性を，充分正確に把握しておかねばなら ない。

（6）チャンネリング層の発見汇溫度調査乞の他によつ て発見し, 発見後の採油試験に際しても各層のガス比重 を測定し，綿密沉チェックする要が女る。

（7）今後採油のステーヂが進行した場合，チャンネリ グンガス量の決定にガス比重測定法が邀肞できるか否か 
は, 相当疑問の余地が女る。

なお压大ガスチャンネリングについては，われわれが たえずプロダクションヒストリーを検討していた結果, かなり以前からその徵候が見出されていたことであり， 正常なガス油比と解釈される量以外は，すべてチャンネ リング量とするという考方を基調として計算した結果 と, 今回のガス比重測定からの計算結果は, ほとんど近 い值を示したことをこ〉に書き添えて扣く。

次に以上のような試験結果からの結論は, 压入ガスの チャンネリング量を一応ある面から研究したという消極 的な方法であり,むしろわれわれとしては, いかにして
压大ガスチャンネリングを防止するかということに意を そ〉ぐべきであり, 從つてチャンネリングジーンの改修 作業を第 1 義的な技術的問題としてとりあげて括り，压 大方法についても研究中であることを強調しておく。

謝意この試験を実施するに際して助言を与えられた 東大渻田教授・帝石本社中沢生産部長・牛島同副部長・ 中島油層課長, 現場実測に便宜を与えられた帝石秋田鉱 業所浦井生座課長代理・小倉試鋻室長, 御多忙にかわか らず比重測定に岕たられた秋鈗試験室庭山・庄司両社 員,採取にあたられた諸氏,データ一整理・計算等に盡力 された帝不本社油層課綱島社員に深甚の謝意を表する。 